\title{
Chapter 9 \\ Does Legal Origin Matter for Arms \\ Control Treaty Ratification?
}

\author{
Jeroen Klomp and Robert Beeres
}

\begin{abstract}
Contents

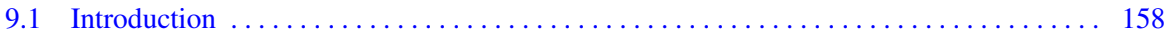

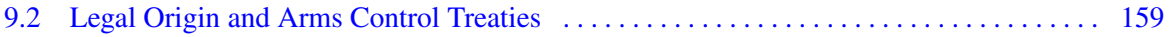

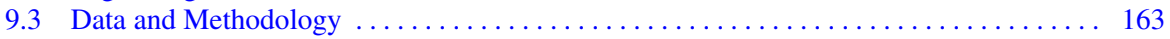

9.3.1 Treaties and Legal Origin Data ............................. 163

9.3.2 Empirical Model .................................... 164

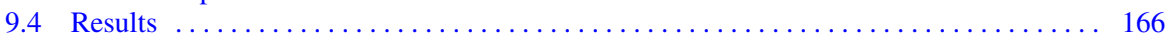

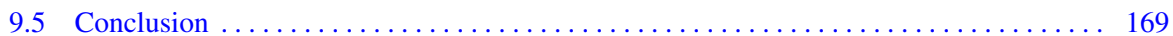

References ................................................ 170
\end{abstract}

\begin{abstract}
This chapter examines whether the legal origin of a country influences the likelihood of ratification of multilateral international treaties concerning arms control. We theorize that ratification of an arms control treaty signals a country's intention to avoid arms races and wars. We know only little about the variation in the ratification of such agreements. One possible element that may explain this variation is the legal origin or tradition of a country. Since treaties are legally binding agreements between two or more states and/or international governmental organizations, they cannot be adapted to local needs and circumstances. Treaties are therefore generally an uneasy fit with the gradual, organic evolution of law that is essential in the common-law system. By contrast, the civil-law tradition neatly distinguishes between legally binding obligations and non-binding guidelines or directives. Consequently, civil-law countries are expected to be more likely to ratify treaties than commonlaw countries. The empirical results clearly confirm this expectation. In particular,
\end{abstract}

\footnotetext{
J. Klomp $(\varangle) \cdot$ R. Beeres

Faculty of Military Sciences, Netherlands Defence Academy, PO Box 90002, 4800 PA Breda, The Netherlands

e-mail: jeroen.klomp@wur.nl

R. Beeres

e-mail: rjm.beeres@mindef.nl

J. Klomp
}

Section Economics, Wageningen University \& Research, PO Box 8130, 6700 EW Wageningen, The Netherlands 
civil-law countries have ratified about nine percent more treaties than common-law countries.

Keywords Legal tradition $\cdot$ common law $\cdot$ civil law $\cdot$ arms control $\cdot$ soft law $\cdot$ international agreements $\cdot$ treaties

\subsection{Introduction}

In April 2013, the Arms Trade Treaty (ATT) was opened for signature after the adaptation by the United Nations General Assembly and entered into force in December 2014. Currently 110 countries have signed and ratified the ATT. Its roots can be traced back to the late 1980s and was a response to the growing concern on the unregulated nature of the global trade in conventional weapons in the preceding decades. Especially the rapid spread of arms in less democratic countries created a serious risk for human security in these countries. The aim of the ATT was to regulate the global arms transfers by establishing a minimal legal basis and improving transparency and cooperation among countries. It is not the first and will for sure not be the last international treaty to manage the international transfer of strategic goods. Currently, there are more than twenty international arms control and non-proliferation treaties in place that are open to all states to become a member. Some are used as ways to stop the spread of certain military technologies such as nuclear weaponry or missile technology (i.e., Non-Proliferation Treaty). Other arms control agreements are entered to limit the trade of conventional arms to state and non-state violent actors (i.e., Arms Trade Treaty).

One important broad question that still is largely unanswered is why some states join certain international treaties, but other states do not? This question is not only relevant from an academic but even more so from a political point of view when drafting new treaties. The typical answer to this question provided in the existing literature is that states join international agreements which are in accordance with their economic interests. ${ }^{1}$ However, not all treaties provide obvious economic benefits to states. When there are no direct monetary gains from international cooperation, as it is the case in arms control treaties, there have to be other benefits of treaty ratification. An alternative motive to ratify arms control treaties builds on the argument that non-proliferation of conventional arms and WMD would bring substantial benefits in ending expensive arms races and redirect resources to more productive purposes. ${ }^{2}$ Broadly speaking, these benefits can roughly be divided into two categories. First, signing an arms control treaty might provide some strategic benefits as state leaders benefit from peaceful international relations, increased gains from trade and from the ability to enforce their own policy goals in the international arena. Voters are likely to

\footnotetext{
${ }^{1}$ Congleton 2006; DeLeat and Scott 2006; Fredriksson et al. 2007; Fredriksson and Ujhelyi 2006; Hollyer and Rosendorff 2011; Mansfield et al. 2002; Miller 1984; Milner and Rosendorff 1997; Neumayer 2002; Rosendorff 2005; Vreeland 2008.

${ }^{2}$ Levine and Smith 2000.
} 
reward this strategic policy. This will, in turn, increase the likelihood that incumbent officials will be re-elected during the next elections. ${ }^{3}$ Second, state leaders face costs of arms races and escalation of international conflicts. The ratification of arms control treaties reduces the risk of war for certain countries and therefore reduces the costs of war and arms races. Thus, the conclusion of arms control treaties increases international security and stability, because these agreements have an important signalling function. They provide information about peaceful intentions and the willingness to employ offensive capabilities because they require all treaty partners to reduce their offensive weapons arsenal or to limit the range of weapons used. ${ }^{4}$ With such a signal, states can escape or slow down arms races and prevent conflicts from escalation to war.

Additionally, many studies examine the institutionalization of treaties through ratification. ${ }^{5}$ A possible key element that affects the decision of whether or not to ratify a particular treaty is the legal tradition of a country. This issue is mainly neglected in the current literature. The world's legal systems can roughly be divided between two major traditions: English common law and French civil law. Since treaties are legally binding agreements between two or more states, they cannot be adapted to local needs and circumstances. Treaties are therefore generally inconsistent with the gradual, organic evolution of law that is essential in the common-law system. As a result, common-law countries hold a distaste for treaties. In turn, treaties are a more comfortable fit with the civil-law tradition that neatly distinguishes between law and non-law. Consequently, civil-law countries are expected to ratify binding international obligations.

The aim of this chapter is to provide an insight into the relationship between the legal tradition of a country and the ratification of arms control treaties. For this purpose, an ordered logit model is estimated including 171 countries. The main findings of our study are in accordance with our expectations. Common-law countries ratify fewer arms control treaties compared to civil-law countries.

The remainder of the chapter is structured as follows. Section 9.2 reviews the literature relevant for explaining the relationship between arms control treaties ratification and legal origin. Section 9.3 describes the data and methodology used, while Sect. 9.4 shows our empirical results. Last, Sect. 9.5 offers a conclusions and discussion.

\subsection{Legal Origin and Arms Control Treaties}

The international transfer of sensitive and military-strategic goods, including nuclear weapons, conventional arms and dual-use goods, are subject to specific international treaties. This framework is designed to prevent weapons systems, technologies,

\footnotetext{
${ }^{3}$ Brender 2018.

${ }^{4}$ Kydd 2000; Müller 2000.

${ }^{5}$ Bernauer et al. 2010; Haftel and Thompson 2013; Hathaway 2007; Neumayer 2008; Schneider and Urpelainen 2013; Simmons and Danner 2010; Von Stein 2008.
} 
knowledge and services, posing threats to international safety and security, from falling in the hands of violent state and non-state actors. International treaties are widely used as a common tool of global governance the last decades. A treaty is a legally binding agreement between two or more nations and or organization that is recognized and given effect under international law. One of the most important principles of treaty law is pacta sunt servanda (i.e., the pact must be respected), meaning that treaties are binding on the parties by consent and must be performed by them in good faith. ${ }^{6}$

The existing literature shows that the ratification of a particular treaty is mainly determined by political and economic interests. One important issue in this debate that has not been explored so far is whether the decision to ratify international treaties is affected by the legal tradition of a country, as this will shape the incentives of policymakers. Juridical scholars typically classify the legal tradition according to: (i) historical background and development of the legal system; (ii) theories and hierarchies of sources of laws; (iii) the working methodology of jurists; (iv) the characteristics of the legal concepts; (v) the legal institutions of the system; and (vi) the divisions of law employed. ${ }^{7}$ Using this framework, legal origin theory formalizes the different perspectives about law and its purpose and classify the legal origin of a country into two secular principal traditions: common law and civil law, and several subtraditions-French, German, socialist, and Scandinavian-within the civil-law tradition. Generally, the two principal types of legal origins emerged from the different views of law developed in England and France centuries ago. These contrasting views yielded diverging ideas and strategies that are not only incorporated into specific legal rules and codes, but also into the organization of the legal system. Civil law encourages a centralized system where the government directly addresses market failures, whereas the more decentralized common-law approach favours contract and private litigation. The two principal legal traditions have been transplanted through colonization and conquests to the vast majority of the jurisdictions in the world by a group of European countries. ${ }^{8}$

The common-law legal tradition was developed in England first and later spread across the colonies of the British empire, including the United States, Canada, Australia, India, South Africa. English common law developed because landed aristocrats and merchants wanted a system of law that would provide strong protections for property and contract rights, and limit the crown's ability to interfere in markets. ${ }^{9}$ The judge has a central role in the common-law system. The law is formed by appellate judges who establish binding precedents by resolving case-specific disputes. Dispute resolution tends to be adversarial rather than inquisitorial. Judicial independence from both the executive and legislature are central. The civil-law tradition is the oldest, the most influential, and the most widely distributed around the world, especially after so many transition economies after the end of the Cold War have

\footnotetext{
${ }^{6}$ Abbott and Snidal 2000; Guzman and Meyer 2010; Lipson 1991; Raustiala 2005.

${ }^{7}$ Glendon et al. 1982.

${ }^{8}$ David and Brierley 1985; McNeill and McNeill 2003.

${ }^{9}$ Mahoney 2001.
} 
returned to it. It originates from Roman law and uses statutes and comprehensive codes as a primary means of ordering legal material. Dispute resolution tends to be inquisitorial rather than adversarial. In the civil-law system statutes and comprehensive codes serve as the primary means of ordering legal material, with a key role for legal scholars who ascertain and formulate rules.

It has been widely documented in the political science and economics literature that legal origin significantly influences the political decisions on implementing and enforcing various kinds of laws and regulations. For instance, empirical analyses demonstrate that common-law states are more market-oriented by having more economic freedom, stronger investor protection, more private ownership, more flexible labour markets, less burden of firm entry regulations and more developed capital markets than states with civil law, Islamic law, or mixed legal traditions. In contrast, civil law is associated with a heavier hand of government ownership and state-desired allocations. In other words, civil law is "policy implementing", while common law is "dispute resolving". ${ }^{10}$ These economic outcomes are not only explained by the content or application of law, but also by the organization of the law system in countries. Subsequent studies have found that common law is associated with a lower formalism of judicial procedures and a greater judicial independence than civil law. These results are associated with better contract enforcement and greater security of property rights. ${ }^{11}$

The influence of legal traditions reaches beyond national boundaries into the realm of international commitments. A series of studies identify differences between civillaw and common-law countries in terms of their willingness to join treaties or accept the jurisdiction of international courts. ${ }^{12}$ The main conclusion shared among these studies suggest that common-law countries are less likely to show such willingness compared to civil-law countries.

One essential element of common-law systems is their bottom-up evolution. Law is made by judges as a means to solve specific social problems. Legal rules evolve gradually and are sensitive to the social environment in which they operate and correspond with its values. ${ }^{13}$ International treaties, however, are inconsistent with the notion of local, organic, and socially adaptive law. Foreign documents produced by international political deals are imposed top-down on the legal system and do not necessarily reflect its values. As a result, international treaties may not fit comfortably with its existing legal culture of rules and practices. These concerns lead commonlaw countries to greatly value the flexibility of nonbinding international rules and the liberty to modify or disregard provisions that are incompatible with domestic laws and policies. Additionally, given the power and independence of judges in common-law systems, governments feel uncertain about the consequences of treaty

\footnotetext{
${ }^{10}$ Botero et al. 2004; Djankov et al. 2002; 2003a; La Porta et al. 1997; 1998; 1999; 2002.

${ }^{11}$ La Porta et al. 2004; Djankov et al. 2003b.

${ }^{12}$ Chapman and Chaudoin 2013; Efrat 2016; Elkins et al. 2006; Goodliffe and Hawkins 2006; Mitchell and Powel 2011; Simmons 2009.

${ }^{13}$ Gennaioli and Shleifer 2007; Hutchinson 2005.
} 
ratification and may find it difficult to escape treaty obligations. ${ }^{14}$ To influence state behaviour, international agreements typically require incorporation into the domestic legal system and integration into domestic institutions. Implementation-the introduction of international rules and norms into formal legal and policy mechanisms within a state-is a key process in the translation of these rules and norms into changes in actual behaviour. ${ }^{15}$ When incorporating a treaty into the domestic legal system, local law has to be brought into line with the treaty's legal obligations. In a common-law system, assessing the conformity of local law with the treaty-and making necessary changes_-presents a challenge since the common law is not found in a single major code. Rather, law exists as an amalgam of statutes and legal precedents. Combing through the numerous legal sources and adjusting them to the treaty could be time-consuming and difficult.

Whereas common-law systems are less comfortable with legally binding agreements, the reverse might be true for civil-law systems as the flexibility of the legal rule comes at the expense of its certainty - and it is the latter that civil law values more. In contrast, nonbinding agreements do not easily fit civil law's emphasis on certainty, clarity, and formal legal sources, and its neat distinction between law and non-law. Civil law sees formal international rules as the preeminent means for governing interstate relations. $^{16}$

To summarize the discussion above, common-law systems are more comfortable with nonbinding agreements than with treaties as they are less flexible and are an uneasy fit with the common-law legal tradition. By contrast, civil law's emphasis on certainty, the preference for formal, established sources and the separation of law and non-law will result in an inclination toward treaties and a distaste toward nonbinding commitments. Treaties fall neatly in the legal domain and are the international equivalent of the civil code that is a main pillar of the civil-law system. ${ }^{17}$ Hence, civil-law systems feel more comfortable with treaties than with nonbinding agreements. Nonbinding international instruments are relegated to the non-law sphere and are not seen as an established source of international law. Overall, given civillaw's affinity for binding agreements and common law's aversion to them, we would expect a higher ratification rate of international arms control treaties among civil-law countries.

\footnotetext{
${ }^{14}$ McLean 2012.

${ }^{15}$ Betts and Orchard 2014.

16 Jouannet 2006.

${ }^{17}$ Koch 2003.
} 


\subsection{Data and Methodology}

\subsubsection{Treaties and Legal Origin Data}

We have developed a database on the membership status of states in international treaties concerning weapons based on the information provided by the United Nations Office for Disarmament Affairs (UNODA). The analysis here focuses on those treaties including the additional protocols that are open for all states to become member of the treaty. Including all treaties would inflate ratification for some countries, compared to others which have not the option to become a member of those treaties. Following Brender protocols of the Convention on Certain Conventional Weapons which require individual ratification of members will be dealt with as if they are a treaty of their own. These protocols are, for instance, land mines, blinding lasers, booby traps, and explosives. ${ }^{18}$ The reason is that the control of certain weapons is governed by these protocols. The nineteen arms control treaties dealt with in this chapter can be roughly divided into two groups. First, there are those treaties specifying the terms of peaceful use of certain resources and areas. ${ }^{19}$ Second, there are treaties prohibiting the development, trade, stockpiling and use of specific weapons. ${ }^{20}$

A country's legal origin is measured by its respective tradition using dummy variables. This classification is based on the differences between the highest legal source of law, because this predominantly defines the main characteristics of legal systems. Initially, the legal origin of a country is either classified as common or civil law. The highest source of law for common law is case law, while for civil law this is codified standards. Within the civil-law tradition, we are able to identify three particular branches, the French code (or Napoleonic code, that dates back

\footnotetext{
${ }^{18}$ Brender 2018.

${ }^{19}$ Specifically, these are the Antarctic Treaty, signed in 1959, guaranteeing that only peaceful, scientific missions will be conducted in the Antarctic; the Partial Test Ban Treaty from the year 1963, which restricts nuclear testing to the underground; the Outer Space Treaty from 1967, securing the peaceful use of outer space and celestial bodies and which prohibits the placement of weapons of mass destruction in the orbit and on celestial bodies; the Seabed Treaty, signed in 1971, which provides that no weapons of mass destruction should be placed on the seabed beyond territorial waters; the Moon Treaty signed in 1979, concerning the jurisdiction of the moon; and lastly the Open Skies Treaty from 1992, which allows for regular overflight of national territories on certain routes for verification purposes.

${ }^{20}$ The Geneva Protocol being the first international agreement to prohibit the use of biological and chemical weapons in war and therefore the first treaty which prohibits the use of a weapon type. It is followed by the Treaty on the Non-Proliferation of Nuclear Weapons in 1968; the Biological Weapons Convention in 1972; which bans not only the use, but also the production and stockpiling of biological weapons; the Convention on the Prohibition of Military or Any Other Hostile Use of Environmental Modification Techniques in 1977; the Convention on Certain Conventional Weapons in 1981 with Protocols I-V restricting the use of weapons with non-detectable fragments (Protocol I), landmines and booby traps (Protocol II), incendiary weapons (Protocol III), blinding laser weapons (Protocol IV) and Protocol V which governs the clearance of explosive remnants of war; the Chemical Weapons convention in 1993; the Anti-Personnel Mines Ban Convention in 1997 and the Convention on Cluster Munition in 2003.
} 
Table 9.1 Distribution of the legal origin

\begin{tabular}{l|l}
\hline Common law & $32 \%$ \\
\hline Civil law of which & $68 \%$ \\
\hline French law & $52 \%$ \\
\hline German law & $11 \%$ \\
\hline Scandinavian law & $3 \%$ \\
\hline
\end{tabular}

Source Klomp and Beeres 2021

to the 1800s), the German code (enacted by Bismarck in the late 1800s) and the Scandinavian code (that dates back to the 1700s). The data is collected from La Porta, Lopez-de Silanes and Schleifer and Mitchell and Powell. ${ }^{21}$ In Table 9.1, we report the distribution of the different legal systems across our global panel.

As a preliminary statistical test, we compute the number of arms control treaties for civil-law and common-law countries. On average, a common-law state has ratified about 6.3 treaties, while a civil-law state has ratified approximately 7.1 treaties. This difference is statistically significant at the ninety percent significance level. This finding implies that civil-law countries are associated with more arms control treaty ratification. However, this nonparametric test is only suggestive, as unobserved country heterogeneity, as well as other confounding variables, are not taken into account.

\subsubsection{Empirical Model}

To find out whether legal origin influences the ratification of arms control treaties, we employ an ordered logit model using a panel dataset including 171 countries over the period 1975-2016. Ordered logit estimation is appropriate when the dependent variable data is in an ordinal ordering. In this analysis, a higher number of treaties ratified correspond to a higher level of commitment intention than fewer treaties ratified. ${ }^{22}$ However, one drawback of this approach is that we assume that all treaties are equally important for arms trade control. The model is given as follows.

$$
\text { treat }_{i t}=\alpha_{i}+\beta^{k} x_{i t-m}^{k}+\gamma \text { legal }_{i}+\varepsilon_{i t}
$$

The dependent variable treaty $_{i t}$ is the cumulative number of treaties a country $i$ has ratified at the end of year $t$. The vector $x^{k}$ contains $k$ control variables, while the variable legal $_{i}$ captures the legal origin of a country using a series of dummies indicating whether a nation has a common-law or civil-law origin and the various subdivisions. The parameter $\alpha_{i}$ is a country-specific intercept, while $\varepsilon_{i t}$ is an error term.

\footnotetext{
${ }^{21}$ La Porta et al. 2008; Mitchell and Powell 2011.

22 Brender 2018; Neumayer 2002.
} 
Table 9.2 Data used

\begin{tabular}{|c|c|c|}
\hline Variable & Description & Source \\
\hline Real GDP per capita & $\begin{array}{l}\text { Real GDP per capita in constant } \\
\text { US dollars of } 2005 \text { (in logarithm) }\end{array}$ & World Bank (2018) \\
\hline Growth rate of real GDP & $\begin{array}{l}\text { Growth rate of the real GDP per } \\
\text { capita }\end{array}$ & World Bank (2018) \\
\hline Military officer & $\begin{array}{l}\text { Dummy variable taking the value } \\
\text { one when the incumbent leader } \\
\text { or Minister of Defence has a } \\
\text { military rank, zero otherwise }\end{array}$ & Scartascini et al. 2018 \\
\hline Civil rights & $\begin{array}{l}\text { Freedom House sub score on } \\
\text { civil rights }\end{array}$ & Freedom House 2018 \\
\hline Democratic accountability & Polity IV score & Marshall et al. 2019 \\
\hline Foreign aid & $\begin{array}{l}\text { Official Development Assistance } \\
\text { as a share of GDP }\end{array}$ & World Bank (2018) \\
\hline Trade openness & $\begin{array}{l}\text { Sum of import and export as a } \\
\text { share of total GDP }\end{array}$ & World Bank (2018) \\
\hline Military trade & $\begin{array}{l}\text { Total values in constant US } \\
\text { dollars of the exports plus } \\
\text { imports of military goods and } \\
\text { services (taken in logarithms) }\end{array}$ & World Bank (2018) \\
\hline Size of the armed forces & $\begin{array}{l}\text { Total size of the military staff } \\
\text { and personnel as a share of the } \\
\text { adult population }\end{array}$ & World Bank (2018) \\
\hline UNSC member & $\begin{array}{l}\text { Dummy variable that is one if a } \\
\text { country is a temporarily or } \\
\text { permanent member of the United } \\
\text { Security Council in a particular } \\
\text { year, zero otherwise }\end{array}$ & $\begin{array}{l}\text { https://www.un.org/securitycoun } \\
\text { cil// }\end{array}$ \\
\hline Total population & $\begin{array}{l}\text { Total number of inhabitants } \\
\text { within a country (in logarithm) }\end{array}$ & World Bank (2018) \\
\hline Number of veto players & $\begin{array}{l}\text { Political constraint index: the } \\
\text { number of veto players in the } \\
\text { political system }\end{array}$ & Henisz 2017 \\
\hline
\end{tabular}

Source Klomp and Beeres 2021

The vector of control variables is based on earlier literature on the ratification and implementations of international treaties in general and arms control treaties more specific. ${ }^{23}$ These variables are required to avoid an omitted variable bias. The decision of whether or not to ratify a particular arms control treaty is generally based on different considerations including economic, political and security concerns. Table 9.2 provides an overview of all control variables, their definition as well as their

${ }^{23}$ Brender 2018; Congleton 2006; DeLeat and Scott 2006; Fredriksson et al. 2007; Fredriksson and Ujhelyi 2006; Hollyer and Rosendorff 2011; Mansfield et al. 2002; Miller 1984; Milner and Rosendorff 1997; Neumayer 2002; Rosendorff 2005; Vreeland 2008. 
source. All explanatory variables are lagged to avoid simultaneity and endogeneity problems. The optimal number of lags $m$ for each control variable is determined by using the Schwarz Bayesian Information Criterion.

Before estimating the model, we have to solve two further estimation problems that are related with the panel setting. First, the maximum number of treaties that could be ratified by a country differs between the start and the end of our period. To control this issue, we add a variable taking the value that is equal to the total number of treaties that are opened for signing and ratification. Second, we have to choose between a fixed-effects model and a random-effects model when estimating the model. However, since our primary variable of interest - the indicator for the legal origin-is time-invariant at country level, we are constrained to use the randomeffects estimator. Our model cannot be estimated using fixed-effects because the legal origin dummy would be collinear with the country-specific dummies.

\subsection{Results}

Table 9.3 presents the baseline results of the ordered logit model. To obtain robust standard errors, we apply the bootstrap estimator with 1,000 replicators and cluster them on country levels. Since it is difficult to directly interpret the standard coefficients of a logit model as they are in log-odds units, we report the marginal effects in percentage-points. ${ }^{24}$ Table 9.3 , column 1 includes all control variables suggested in the previous section. To control for the legal origin, we include a dummy variable taking the value one when a state has a civil-law history and zero otherwise. This means that we use common-law countries as our reference category. The results suggest that there is no significant difference in ratifying arms control treaties between civil-law and common-law states.

However, one problematic concern is that the used classification of the legal system is rather rough, making it less informative. As a result, it reduces variation among countries and the explanatory power of the legal origin indicator. In particular, there is no general consensus on how this legal origin division should be made exactly. ${ }^{25}$ According to the existing literature, there is some significant heterogeneity among the countries currently classified as civil or common law. According to Mitchell and Powell some countries that are initially recorded as common-law ones, should actually be considered as Islamic or Sharia Law (such as Pakistan and Sudan) or have a mixed law system (such as Israel or South Africa). ${ }^{26}$ Mixed law also includes numerous countries of Africa as it is partly based on tribal or customary law. Likewise, China's system is largely civil mixed with principles of socialist law and traditional Confucian values. ${ }^{27}$ Table 9.3, column 2 uses a broader classification. In more detail,

\footnotetext{
${ }^{24}$ Cameron and Trivedi 2009.

${ }^{25}$ David and Brierley 1985; Glenn 2014; Zweigert and Kotz 1998.

${ }^{26}$ Mitchell and Powell 2011.

${ }^{27}$ Schaffer et al. 2011.
} 


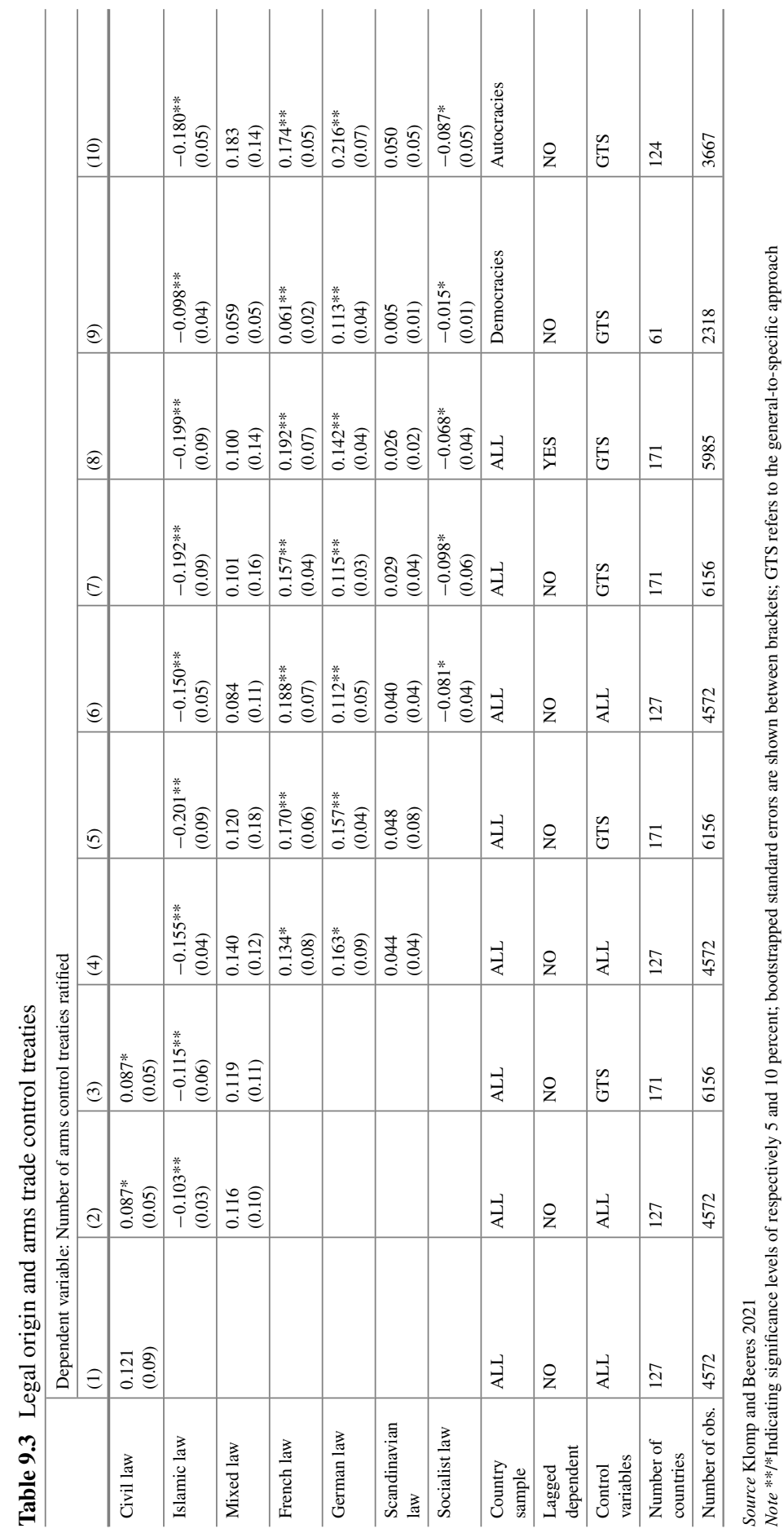


Islamic law is based on religious writings, while mixed systems combine elements of two or more different legal systems including customary law.

The findings point out that civil-law countries are more likely to ratify a particular arms control treaty compared to common-law countries. This difference is statistically significant at the ninety percent confidence level. In turns out that civil-law countries ratify about nine percent more arms control treaties compared to countries with a common-law heritage. Additionally, the results also indicate that Islamic countries are less likely to ratify arms control treaties than common-law or civillaw countries, while the impact of mixed law is the same compared to common-law countries as this legal origin variable is statistically insignificant.

Due to reasons of data availability, using all suggested control variables in one specification reduces our dataset substantially thereby increasing the risk that the results are driven by a sample selection bias. To balance the omitted variable bias against a possible sample selection bias, Table 9.3, column 3 presents our set of control variables by applying the general-to-specific method. This method does not rely on economic theory, but is a widely-used method in applied econometrics to decide on the model specification. ${ }^{28}$ We first estimate a model including all control variables as outlined in the previous section, but without including our legal origin dummies. Next, we drop the least significant variable and estimate the model again. This procedure is repeated until only variables that are significant at the ten percent level remain. The results in Table 9.3, column 3 are rather identical compared to the findings in Table 9.3, column 2. This indicates that the results are quite robust to the econometric specification chosen.

In Table 9.3 (columns 4 and 5), we split the sample of civil-law countries a little further into countries of German, French and Scandinavian origin. The results indicate that although countries that have a civil-law tradition are more likely to ratify an arms control treaty than common-law ones, there is any statistically significant difference within the group of civil-law countries. On a similar note, earlier empirical studies indicate that socialist legal systems should be considered as a separate category. A socialist system is driven by the administration implying that there is no role for private law, the country is governed by one dominant communistic party, the law is predominately used to realize a political agenda and court rulings hardly settle disputes in private relations and have a limited role in public law. The classification used so far does not distinguish the socialist tradition. Instead, former socialist countries are reclassified as either German or French according to the main historical influence on their new legal system. For example, Russia is classified as having French legal origin. Of the 24 former socialist countries in our sample, 11 have French and 13 have a German origin. In Table 9.3 (columns 6 and 7), we include countries with a socialist legal origin as a separate category. The results show that socialist regimes are rather different from the other civil-law countries as they ratify fewer arms control treaties. In particular, they even ratify fewer treaties than common-law countries as the coefficient is significantly negative at common confidence levels. Furthermore, in the econometric specification in Table 9.3 column 8, we include the

${ }^{28}$ Hendry 1993. 
number of treaties ratified in the previous year as an additional covariate. Although the magnitude and significance both drop slightly of the variables of interest, adding the dependent variable with a one-year lag does not dramatically affect our main conclusions as civil-law countries still ratify more arms control treaties compared to other systems.

Finally, leaders of democratic states face constraints autocrats do not have to take into account when making ratification decisions. According to the existing literature, regime differences play an essential role in treaty ratification. ${ }^{29}$ One crucial assumption we made so far is that there is no difference between the de jure and de facto of the applied legal system in a country. The classification of legal systems is based on the source of law that is the highest in hierarchy including legal documents or written procedures. As a result, our indicator is not directly related with the execution or actual practice of law and legislation. For instance, in autocratic regimes laws and institutions are primarily built and shaped to promote the personal interests of the ruling elite, making the legal origin less important. This could for instance explain the negative effect found on socialist and Islamic legal origin as many countries with these legal systems can be classified as autocratic or at least democratic transition countries. Generally, autocratic regimes have ratified about six treaties, whereas democracies have ratified about ten treaties. To explore this issue some further, we split our data into democratic and autocratic countries based on the Polity IV score. Each country-year with a Polity IV score larger or equal to seven are recorded as democratic. As expected, the final columns of Table 9.2 indicate that the gap between common-law and civil-law countries is larger in democracies as in these countries the difference between de jure and de facto is less compared to autocratic states. This gap between common law and civil law is only weakly significant in autocratic countries as the legal origin is of less importance in these countries. Laws and policies are more shaped by the self-interest of the ruling elite than by the legal tradition.

\subsection{Conclusion}

The objective of this chapter is to explore whether the legal origin of a country influences the number of arms control treaties that are ratified. Given civil law's affinity for binding agreements and common law's aversion to them, we would expect a higher likelihood of ratification of international arms control treaties among civillaw countries. After testing for the robustness of the results, we can draw a number of conclusions based on the findings reported throughout this chapter. First, civil-law countries ratify more arms control treaties than common-law countries. In particular, civil-law countries ratify about nine percent more treaties. In practice, this comes down to about two arms control treaties. Second, within the broad civil-law category, we find no significant difference between countries with a French, German or Nordic

${ }^{29}$ Congleton 2006; Hollyer and Rosendorff 2011; Mansfield et al. 2002; Neumayer 2002. 
legal heritage. Third, Islamic and socialist law countries ratify fewer arms control treaties compared to other legal traditions. Finally, the ratification gap between civillaw and common-law countries is larger for democracies than for autocracies. This can be explained by the fact that laws and policies in autocracies are shaped more by the self-interest of the ruling elite than by the legal tradition of a country.

These results imply that when drafting an international arms control treaty, politicians should take into account the legal tradition of a country. One way to make treaties more effective is by giving countries the opportunity to partly modify or disregard provisions on less important issues that are incompatible with domestic laws and policies.

Two major limitations regarding our study are, first, that we assume that all arms control treaties are equally important. This is not necessarily the case. Some treaties have a broader scope or are more stringent than others. So their implications differ as well as their importance differ. Second, we have only explored the incentives of ratifying an arms control treaty and have not looked at the implementation in the national law. Treaties often come with enforcement problems, raising considerable concerns about the actual implementation of treaty provisions. The existing literature has already shown there are serious concerns about arms control implementation and compliance.

\section{References}

Abbott KW, Snidal D (2000) Hard and soft law in international governance. International Organization 54:421-456

Bernauer T, Kalbhenn A, Koubi V, Spilker G (2010) A comparison of international and domestic sources of global governance dynamics. British Journal of Political Science 40:509-538

Betts A, Orchard P (eds) (2014) Implementation and world politics: how international norms change practice. Oxford University Press, Oxford

Botero JC, Djankov S, Porta RL, Lopez-de Silanes F, Shleifer A (2004) The regulation of labor. The Quarterly Journal of Economics 119:1339-1382

Brender A (2018) Determinants of international arms control ratification. ILE Working Paper Series 17. University of Hamburg, Hamburg

Cameron AC, Trivedi PK (2009) Microeconometrics Using Stata. Stata Press, College Station, Texas

Chapman TL, Chaudoin S (2013) Ratification patterns and the International Criminal Court. International Studies Quarterly 57:400-409

Congleton RD (2006) International public goods and agency problems in treaty organizations. The Review of International Organizations 1:319-336

David R, Brierley JE (1985) Major legal systems in the world today: an introduction to the comparative study of law. Stevens and Sons, London

DeLeat CJ, Scott JM (2006) Treaty-making and partisan politics: Arms control and the US Senate, 1960-2001. Foreign Policy Analysis 2:177-200

Djankov S, Glaeser E, La Porta R, Lopez-de Silanes F, Shleifer A (2002) The Regulation of Entry. Quarterly Journal of Economics 117:1-37

Djankov S, Glaeser E, La Porta R, Lopez-de Silanes F, Shleifer A (2003a) The New Comparative Economics. Journal of Comparative Economics 31:595-619 
Djankov S, Glaeser E, La Porta R, Lopez-de Silanes F, Shleifer A (2003b) Courts. Quarterly Journal of Economics 118:453-517

Efrat A (2016) Legal Traditions and Nonbinding Commitments: Evidence From the United Nations' Model Commercial Legislation. International Studies Quarterly 60:624-635

Elkins Z, Guzman AT, Simmons BA (2006) Competing for capital: The diffusion of bilateral investment treaties, 1960-2000. International Organization 60:811-846

Fredriksson PG, Ujhelyi G (2006) Political institutions, interest groups, and the ratification of international environmental agreements. Unpublished Manuscript. Department of Economics, University of Houston, Texas

Fredriksson PG, Neumayer E, Ujhelyi G (2007) Kyoto Protocol cooperation: Does government corruption facilitate environmental lobbying? Public Choice 133:231-251

Freedom House (2018) Freedom in the World 2017

Gennaioli N, Shleifer A (2007) The evolution of common-law. Journal of Political Economy 115:4368

Glendon M, Gordon M, Osakwe C (1982) Comparative Legal Traditions in a Nutshell. West Publishing, St. Paul

Glenn HP (2014). Legal traditions of the world: Sustainable diversity in law. Oxford University Press, Oxford

Goodliffe J, Hawkins DG (2006) Explaining Commitment: States and the Convention against Torture. The Journal of Politics 68:358-371. https://doi.org/10.1111/j.1468-2508.2006.00412.x

Guzman AT, Meyer TL (2010). International soft law. Journal of Legal Analysis 2:171-225

Haftel YZ, Thompson A (2013) Delayed ratification: The domestic fate of bilateral investment treaties. International Organization 67:355-387

Hathaway OA (2007) Why do countries commit to human rights treaties? Journal of Conflict Resolution 51:588-621

Hendry DF (1993) Econometrics: alchemy or science? Essays in econometric methodology. Oxford University Press, Oxford

Henisz WJ (2017) The political constraint index (POLCON) dataset. Available from: https://mgmt. wharton.upenn.edu/faculty/heniszpolcon/polcondataset/

Hollyer JR, Rosendorff P (2011) Domestic politics and the accession of authoritarian regimes to human rights treaties. Quarterly Journal of Political Science 6:275-327

Hutchinson AC (2005) Evolution and the Common Law. Cambridge University Press, New York

Jouannet E (2006) French and American perspectives on international law: Legal cultures and international law. Maine Law Review 58:292-337

Koch Jr. CH (2003) Envisioning a global legal culture. Michigan Journal of International Law 25:1-76

Kydd A (2000) Trust, Reassurance, and Cooperation. International Organization 54:325-57

La Porta R, Lopez-de Silanes F, Pop-Eleches C, Shleifer A (2004) Judicial Checks and Balances. Journal of Political Economy 112:445-470

La Porta R, Lopez-de Silanes F, Shleifer A (2008) The economic consequences of legal origins. Journal of Economic Literature 46:285-332

La Porta R, Lopez-de Silanes F, Shleifer A, Vishny R (1997) Legal Determinants of External Finance. Journal of Finance 52:1131-1150

La Porta R, Lopez-de Silanes F, Shleifer A, Vishny R (1998) Law and Finance. Journal of Political Economy 106:1113-1155

La Porta R, Lopez-de Silanes F, Shleifer A, Vishny R (1999) The Quality of Government. Journal of Law, Economics, and Organization 15:222-279

La Porta R, Lopez-de Silanes F, Shleifer A, Vishny R (2002) Investor Protection and Corporate Valuation. Journal of Finance 57:1147-1170

Levine P, Smith R (2000) Arms export controls and proliferation. Journal of Conflict Resolution 44:885-895

Lipson C (1991) Why are some international agreements informal? International Organization 45:495-538 
Mahoney PG (2001) The Common Law and Economic Growth: Hayek Might Be Right. The Journal of Legal Studies 30:503-525

Mansfield ED, Milner HV, Rosendorff BP (2002) Why democracies cooperate more: Electoral control and international trade agreements. International Organization 56:477-513

Marshall MG, Gurr TR, Jaggers K (2019) Polity IV project: political regime characteristics and transitions, 1800-2018. Center for Systemic Peace

McLean D (2012) International Co-operation in Civil and Criminal Matters, 3rd edn. Oxford University Press, Oxford

McNeill JR, McNeill WH (2003) The human web: a bird's-eye view of world history. Norton, New York/London

Miller S (1984) Politics over Promise: Domestic Impediments to Arms Control. International Security 8:67-90

Milner HV, Rosendorff BP (1997) Democratic politics and international trade negotiations: Elections and divided government as constraints on trade liberalization. Journal of Conflict Resolution 41:117-146

Mitchell SM, Powell EJ (2011) Domestic law goes global: Legal traditions and international courts. Cambridge University Press, New York

Müller H (2000) Compliance Politics: A Critical Analysis of Multilateral Arms Control Treaty Enforcement. The Nonproliferation Review 7:77-90

Neumayer E (2002). Do Democracies Exhibit Stronger International Environmental Commitment? A Cross-Country Analysis. Journal of Peace Research 39:139-64

Neumayer E (2008) Death penalty abolition and the ratification of the Second Optional Protocol. International Journal of Human Rights 12:3-21

Raustiala K (2005) Form and substance in international agreements. American Journal of International Law 99:581-614

Rosendorff BP (2005) Do Democracies Trade More Freely? SSRN. https://doi.org/10.2139/ssrn. 1007288

Scartascini C, Cruz C, Keefer P (2018) The database of political institutions 2017 (DPI2017). Banco Interamericano de Desarrollo, Washington

Schaffer R, Agusti F, Dhooge LJ, Earle B (2011) International business law and its environment, 8th edn. South Western Cengage Learning, Mason $\mathrm{OH}$

Schneider CJ, Urpelainen J (2013) Distributional conflict between powerful states and international treaty ratification. International Studies Quarterly 57:13-27

Simmons BA (2009) Mobilizing for Human Rights: International Law in Domestic Politics. Cambridge University Press, New York

Simmons BA, Danner A (2010) Credible commitments and the International Criminal Court. International Organization 64:225-256

Von Stein J (2008) The International Law and Politics of Climate Change: Ratification of the United Nations Framework Convention and the Kyoto Protocol. Journal of Conflict Resolution 52:243-68

Vreeland JR (2008) Political Institutions and Human Rights: Why Dictatorships Enter into the United Nations Convention Against Torture. International Organization 62:65-101

Zweigert K, Kotz H (1998) Introduction to Comparative Law, 3rd edn. Oxford University Press, Oxford

Jeroen Klomp is full professor of arms export control at the Faculty of Military Sciences of the Netherlands Defence Academy and associate professor macroeconomics at the Section Economics of the Wageningen University \& Research. He holds a Ph.D. in political economy from the University of Groningen. His current research involves the economic causes and consequences of strategic trade controls and has been published in numerous peer-reviewed journals. 
Robert Beeres holds a Ph.D. in administrative sciences from Radboud University Nijmegen, The Netherlands. Currently he is a professor of Defence Economics at the Faculty of Military Sciences, Netherlands Defence Academy. His research interests include economics of arms export controls, defence capabilities, performance management and burden sharing within the EU and NATO. He published numerous articles in peer-reviewed journals and books and co-edited a number of books.

Open Access This chapter is licensed under the terms of the Creative Commons Attribution 4.0 International License (http://creativecommons.org/licenses/by/4.0/), which permits use, sharing, adaptation, distribution and reproduction in any medium or format, as long as you give appropriate credit to the original author(s) and the source, provide a link to the Creative Commons license and indicate if changes were made.

The images or other third party material in this chapter are included in the chapter's Creative Commons license, unless indicated otherwise in a credit line to the material. If material is not included in the chapter's Creative Commons license and your intended use is not permitted by statutory regulation or exceeds the permitted use, you will need to obtain permission directly from the copyright holder. 